\title{
Use of the 16S-23S rDNA internal transcribed spacer of Roseovarius crassostreae for epizootiological studies of juvenile oyster disease (JOD)
}

\author{
Aaron P. Maloy ${ }^{1,3}$, Bruce J. Barber ${ }^{2,4}$, Katherine J. Boettcher ${ }^{1,5, *}$ \\ ${ }^{1}$ Department of Biochemistry, Microbiology and Molecular Biology, and ${ }^{2}$ School of Marine Sciences, University of Maine, \\ Orono, Maine 04469, USA \\ ${ }^{3}$ Present address: Centre of Applied Marine Biotechnology, Letterkenny Institute of Technology, Letterkenny, \\ County Donegal, Ireland \\ ${ }^{4}$ Present address: Terra Environmental Services, Inc., 5215 W. Laurel Street, Suite 110, Tampa, Florida 33607-1728, USA \\ ${ }^{5}$ Present address: 11208 Beechwood Pointe, Smithfield, Virginia 23430, USA
}

\begin{abstract}
Juvenile oyster disease (JOD) in Crassostrea virginica is caused by the marine bacterium Roseovarius crassostreae. Although the 16S rRNA genes of the bacterial isolates exhibit little variation, 2 genetic signatures (GSI and GSII) may be discerned by Ava I digestion of the 16S-23S internal transcribed spacer (ITS). In this study we analyzed isolates from JOD epizootics throughout the northeastern USA (including affected adults for the first time) to better understand how oyster populations encounter and become affected by the pathogen. Isolates from a given epizootic usually had the same ITS signature; however, the involvement of both genetic signatures was occasionally detected, even within the same oyster. Sequencing was used to localize the variable Ava I site to a $100 \mathrm{bp}$ region of low sequence identity, and detection of additional base changes resulted in the identification of 11 distinct genotypes. One genotype was found only in Martha's Vineyard, Massachusetts, USA and persisted in JOD survivors. Two genotypes were associated with Maine epizootics, and both were believed to be unique to that region until 2004, when one was detected in Martha's Vineyard among oysters that had survived colonization by the local genotype. Apparent competition between those 2 genotypes was also detected among a population of juveniles. Five genotypes were found only in New York, and the other 3 were isolated from both New York and from around Cape Cod, Massachusetts. Relationships between the geographic occurrence and phylogenetic relatedness of genotypes were compared with regional current patterns to identify possible mechanisms controlling their distribution.
\end{abstract}

KEY WORDS: Juvenile oyster disease · JOD · Roseovarius oyster disease $\cdot$ ROD $\cdot$ Crassostrea virginica $\cdot$ Roseovarius crassostreae $\cdot$ Internal transcribed spacer $\cdot$ ITS $\cdot$ Epizootiology

\section{INTRODUCTION}

Juvenile oyster disease (JOD) causes seasonal mortalities among hatchery produced Crassostrea virginica in the northeastern USA. Most growers in this region deploy newly set juveniles in floating rafts and trays in waters that support rapid growth. An abrupt decrease in growth rate is usually the first indication of an impending epizootic, which in a period of only a few weeks may kill $90 \%$ or more of a first year's crop (Bricelj et al. 1992, Davis \& Barber 1994, Boettcher et al. 1999, Ford \& Borrero 2001). Typical JOD signs include uneven valve margins (which result from the cessation of growth and subsequent erosion of the uncalcified ventral margin of the right valve), mantle lesions, emaciated tissues and deposits of conchiolin 
on the inner valve surfaces (Bricelj et al. 1992, Davis \& Barber 1994, Ford \& Borrero 2001). Epizootics usually occur in the late summer months (Barber et al. 1996, 1998, Boettcher et al. 1999, Ford \& Borrero 2001) and the associated water conditions (e.g. elevated temperatures and salinities) have been reported to enhance JOD transmission under laboratory conditions (Lewis et al. 1996, Paillard et al. 1996). Larger oysters (>25 mm shell height) are not as vulnerable as smaller juveniles (Davis \& Barber 1994, Ford \& Borrero 2001), nor is any species other than $C$. virginica affected.

The most effective management strategies ensure oysters are close to the size-refuge of $25 \mathrm{~mm}$ before the onset of seasonal epizootics (Barber et al. 1996). Other strategies include using selected stocks of oysters that have been bred for fast growth (Barber et al. 1998, Davis \& Barber 1999) or using JOD survivors as broodstock (Lewis 2001). Despite such efforts the annual impact of JOD is unpredictable, and oyster production is limited because of constraints on when seed can be safely deployed. JOD can also occur without warning in previously unaffected areas with disastrous results for growers unaccustomed to dealing with the disease. It is important to understand how JOD emerges in new areas, which in turn requires an understanding of the ecology of the causative agent.

Beginning in 1997, investigations into the etiology of JOD revealed that mortality episodes in Maine were $100 \%$ correlated with colonization by a novel species of the marine $\alpha$-Proteobacteria (Boettcher et al. 1999, 2000). The organism (which belongs to the Roseobacter clade) has since been characterized and named Roseovarius crassostreae (Boettcher et al. 2005). The bacterium is not part of the normal flora of healthy oysters and represents the only organism to be consistently and specifically associated with JOD. Mortality has been reproduced by laboratory challenge (Boettcher et al. 2000), and JOD-like conchiolin has been induced by experimental exposure to $R$. crassostreae (Maloy et al. 2007). Other evidence to support a primary role for $R$. crassostreae includes its consistent isolation from JOD epizootics throughout the northeastern USA (Boettcher et al. 2005) and its presence in oysters immediately preceding the onset of gross JOD signs and mortality (Maloy et al. 2007). The bacterium was formally recognized as the causative agent of JOD at a recent symposium that brought together the accumulated research on the disease (Boettcher et al. 2006). To avoid potential confusion with other diseases of juvenile oysters, we have proposed that JOD be renamed 'Roseovarius oyster disease' (ROD) (Maloy et al. 2007).

The 16S rRNA genes have been sequenced from 26 Roseovarius crassostreae isolates originating from epizootics in Maine, Massachusetts and New York during the years 1997 to 2004 (Boettcher et al. 2005). All sequences share 99.8 to $100 \%$ identity with the type strain CV919-312 ${ }^{\mathrm{T}}$ (a Maine isolate from 1997; Boettcher et al. 1999). These data provided evidence that this is a narrowly defined species and that its association with the oyster host is highly specific. At the same time, it became clear that $16 \mathrm{~S}$ data would be of limited use for epizootiological purposes. For this reason we analyzed the 16S-23S rDNA internal transcribed spacer (ITS) region for informative variation. Length and sequence polymorphisms of bacterial ITS regions have provided data for identifying species (Jensen et al. 1993) and, in some cases, restriction fragment length polymorphism (RFLP) analyses have permitted efficient differentiation between strains (Gürtler \& Stanisich 1996).

In a recent study (Maloy et al. 2005) we described a PCR-based detection and diagnostic assay based on amplification of the Roseovarius crassostreae 16S-23S rDNA ITS region. The procedure uses primers specific for $R$. crassostreae and confirmation of product identity is achieved using RFLP analysis. In this study we conducted PCR-RFLP and DNA sequence analyses of isolates obtained from 1997 to 2004 from JOD epizootics throughout the northeastern USA. The geographic patterns and phylogenetic relatedness of genotypes were then analyzed for clues to how they spread to new areas.

\section{MATERIALS AND METHODS}

Origin of oysters and isolates. JOD-affected Crassostrea virginica were obtained from locations in Maine (from 1997 to 1998, and 2000 to 2004), New York (during the years 2002 to 2004) and Massachusetts (from 2003 and 2004) (Table 1, Fig. 1). In all cases these were active or recent cases of JOD among commercially produced seed that were maintained according to the practices of the individual growers. With the exception of one bottom population of remote-set seed (from Barnstable, Massaschusetts, in 2003) and a few populations of adults (from Katama Bay, Massachusetts, in 2004), oysters were maintained either in upwellers or in floating trays in surface culture. Regardless of location (Fig. 1), the same basic set of disease signs was observed in all populations. These included uneven valve margins, mantle retraction, watery tissues and conchiolin deposition, as well as ongoing or recent mortality.

Bacteriology. Typically, 50 to 200 oysters from each epizootic were individually processed for bacteriology as follows. External fouling was removed and oysters were rinsed with filter-sterilized $70 \%$ seawater (FSSW) prior to aseptic dissection. After dissection general 
Table 1. Roseovarius crassostreae. Genetic signatures of bacteria isolated from juvenile oyster disease (JOD) epizootics. ME: Maine; NY: New York; MA: Massachusetts; DR: Damariscotta River; MB: Maquoit Bay; NM: New Meadows River; SR: Sheepscot River; OB: Oyster Bay; MT: Mattituck; SH: Southold; KB: Katama Bay; EP: Edgartown Great Pond; DN: Dennis; EA: Eastham; BS: Barnstable; MV: Martha's Vineyard; CC: Cape Cod Bay. GSI: genetic signature I (Ava I digest); GSII: genetic signature II (Ava I digest)

\begin{tabular}{|c|c|c|c|c|c|c|}
\hline \multirow{2}{*}{ State } & \multirow{2}{*}{ Year } & \multirow[t]{2}{*}{ Site } & \multirow[b]{2}{*}{$\begin{array}{c}\text { Isolates } \\
\text { screened }^{\mathrm{a}}\end{array}$} & \multicolumn{2}{|c|}{ RFLP analysis } & \multirow[b]{2}{*}{$\begin{array}{c}\text { Oysters } \\
\text { represented }^{b}\end{array}$} \\
\hline & & & & GSI & GSII & \\
\hline \multirow[t]{10}{*}{ ME } & 1997 & DR & 6 & 6 & - & 6 \\
\hline & 1998 & DR & 6 & 6 & - & 6 \\
\hline & 2000 & DR & 2 & - & 2 & 2 \\
\hline & 2000 & MB & 1 & - & 1 & 1 \\
\hline & 2000 & NM & 2 & - & 2 & 2 \\
\hline & 2001 & DR & 2 & - & 2 & 2 \\
\hline & 2001 & SR & 2 & - & 2 & 2 \\
\hline & 2002 & DR & 56 & - & 56 & 49 \\
\hline & 2003 & DR & 15 & - & 15 & 8 \\
\hline & 2004 & DR & 35 & - & 35 & 25 \\
\hline \multirow[t]{6}{*}{ NY } & 2002 & OB & 3 & 2 & 1 & 3 \\
\hline & 2003 & OB & 16 & - & 16 & 4 \\
\hline & 2003 & MT & 1 & 1 & - & 1 \\
\hline & 2004 & OB & 7 & 1 & 6 & 4 \\
\hline & 2004 & MT & 24 & 3 & 21 & 13 \\
\hline & 2004 & $\mathrm{SH}$ & 4 & - & 4 & 4 \\
\hline \multirow[t]{6}{*}{ MA } & 2003 & KB (MV) & 57 & 57 & - & 29 \\
\hline & 2003 & EP (MV) & 3 & 3 & - & 2 \\
\hline & 2003 & $\mathrm{DN}(\mathrm{CC})$ & 2 & - & 2 & 1 \\
\hline & 2003 & $\mathrm{EA}(\mathrm{CC})$ & 18 & 12 & 6 & 7 \\
\hline & 2003 & BS (CC) & 17 & - & 17 & 7 \\
\hline & 2004 & KB (MV) & 227 & 57 & 170 & 143 \\
\hline \multicolumn{7}{|c|}{ 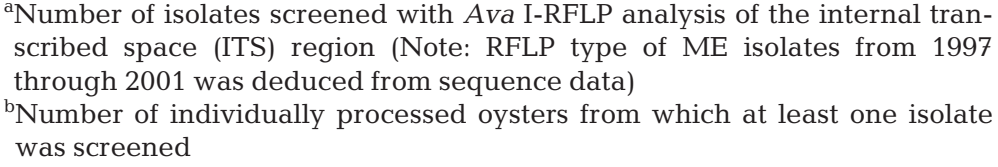 } \\
\hline
\end{tabular}

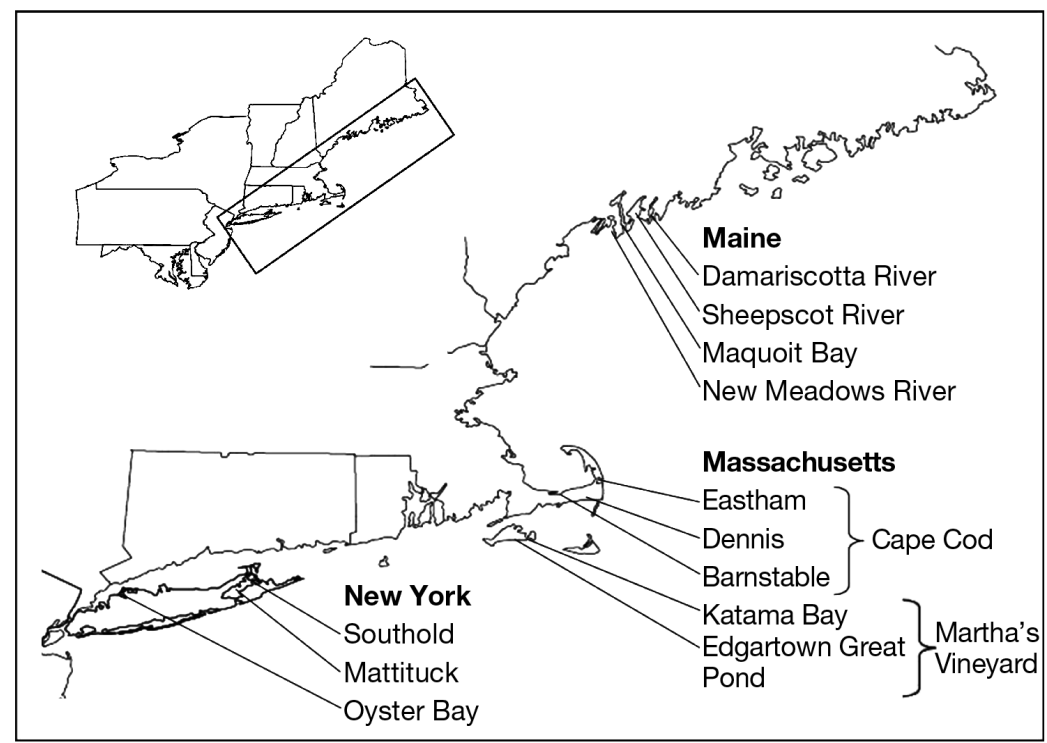

Fig. 1. Northeastern USA indicating sites of juvenile oyster disease (JOD) epizootics from which oyster samples originated heath observations were made and a FSSW-moistened sterile swab was used to collect material from the soft tissues and internal valve surfaces. The swabs were then mixed in $1 \mathrm{ml}$ of FSSW in a vortex mixer to produce a suspension. Serial dilutions of the suspension were plated on seawater tryptone (SWT) agar (Boettcher \& Ruby 1990) and incubated at 23 to $27^{\circ} \mathrm{C}$ for 5 to $7 \mathrm{~d}$ before examination and enumeration of colonies. Identification of Roseovarius crassostreae colonies was based on colony morphology and growth characteristics (Boettcher et al. 2005) and periodically confirmed by PCR amplification and sequencing of the 16S rRNA gene (see next section). Representative isolates were stored at $-80^{\circ} \mathrm{C}$ in an SWT-based glycerol media and all further characterization was performed on subcultures from these frozen stocks.

16S rDNA amplification and sequence analysis. The $16 \mathrm{~S}$ rDNAs of 26 representative Roseovarius crassostreae isolates (at least one from every epizootic) were PCR amplified directly from whole cells using universal primers corresponding to Escherichia coli positions 8 through 27 (27F) and 1492 through 1510 (1492R) (Lane 1991). Each $25 \mu$ reaction contained PCR buffer at $1 \times, 1.5 \mathrm{mM} \mathrm{MgCl}_{2}, 1 \mu \mathrm{M}$ of each primer, $200 \mu \mathrm{M}$ of each deoxynucleoside triphosphate, $1.25 \mathrm{U}$ Taq polymerase (Invitrogen) and approximately $10^{5}$ cells of $R$. crassostreae. Each reaction was run in a programmable thermal controller PTC100 (MJ Research) under the following conditions: $4 \mathrm{~min}$ at $94^{\circ} \mathrm{C}$, followed by 30 cycles of $45 \mathrm{~s}$ denaturing $\left(94^{\circ} \mathrm{C}\right)$, $30 \mathrm{~s}$ annealing $\left(55^{\circ} \mathrm{C}\right), 1.5 \mathrm{~min}$ elongation $\left(72^{\circ} \mathrm{C}\right)$ and an additional $7 \mathrm{~min}$ elongation at $72^{\circ} \mathrm{C}$. Amplicons were filter purified and sequenced at the University of Maine's DNA sequencing facility. Data were edited and unambiguous consensus sequences of at least $1310 \mathrm{bp}$ were produced using Sequence Navigator software (Applied Biosystems).

ITS amplification and RFLP analysis. The 16S-23S rDNA ITS regions of 
the 506 isolates listed in Table 1 were PCR amplified from whole cells using the forward primer ROS-109F (5'-GTTGGTTCTACCTGACGG-3'), which is specific to the $3^{\prime}$ end of the 16S rRNA gene of Roseovarius crassostreae (Maloy et al. 2005), and the reverse primer 115R (5'-GGTTBCCCCATTCRG-3'), which is a published sequence taken from a Roseobacter clade-specific 5' region of the 23S rRNA gene (Söller et al. 2000). Each $25 \mu$ PCR mixture contained PCR buffer at $1 \times$, $1.5 \mathrm{mM} \mathrm{MgCl}_{2}, 0.75 \mu \mathrm{M}$ of each amplification primer, $200 \mu \mathrm{M}$ of each deoxynucleoside triphosphate, $1.25 \mathrm{U}$ Taq polymerase (Invitrogen) and $1 \mu$ l of cell suspension (containing approximately $10^{5} \mathrm{CFU}$ ). Each reaction was run under the following conditions: $3 \mathrm{~min}$ at $95^{\circ} \mathrm{C}$, followed by 35 cycles of $30 \mathrm{~s}$ denaturing $\left(94^{\circ} \mathrm{C}\right), 30 \mathrm{~s}$ annealing $\left(55^{\circ} \mathrm{C}\right), 60 \mathrm{~s}$ elongation $\left(72^{\circ} \mathrm{C}\right)$ and an additional $7 \mathrm{~min}$ elongation at $72^{\circ} \mathrm{C}$. The ITS amplicons were subsequently digested with $5 \mathrm{U}$ Ava I restriction endonuclease (New England Bio Labs). Restriction products were resolved on a $1.5 \%$ agarose gel, stained with ethidium bromide and, based on the number and size of bands, visually scored as either genetic signature I (GSI) or genetic signature II (GSII).

Phylogenetic analyses. Contiguous sequences spanning the entire ITS region were constructed for 103 representative isolates using Sequence Navigator software. Eleven unique genotypes were identified (Genbank accession numbers AF114484 and DQ341296-DQ341305) and manually aligned in MacGDE (version 2.2). This file was then exported to PAUP*4.0b10 (Sinauer Associates) for tree construction using distance criteria. An unrooted phylogram was derived from a heuristic search of 1027 total characters.

Statistical analysis. The relative ability of strains to persist during the co-infection event at Martha's Vineyard in 2004 was tested by comparing the proportion of the total Roseovarius crassostreae population that was comprised by each phenotype. Proportions were transformed $(\arcsin (x)+0.5)$ to conform with model assumptions and analyzed with a General Linear Model ANOVA using Minitab 13.32 (Minitab).

\section{RESULTS}

\section{General observations}

Details regarding mortality, bacteriological analyses, and other features of selected epizootics have been reported previously (Boettcher et al. 1999, 2000, 2005, Maloy \& Boettcher 2003, Maloy et al. 2007). Descriptions of certain populations sampled in 2004 and data regarding phenotype variation and genetic analyses are presented herein.
Of particular importance for this study was the first case of mass mortalities on Martha's Vineyard in 2003, in which affected oysters were heavily and exclusively colonized by a phenotypic variant of Roseovarius crassostreae that produced greenish yellow colonies (Boettcher et al. 2005). When survivors of the Martha's Vineyard 2003 epizootic were sampled again in June of 2004, the oysters had reached 25 to $50 \mathrm{~mm}$ shell height. However, ongoing mortality was observed and bacteriological analyses revealed persistent colonization by $R$. crassostreae. Colonies were obtained which had the same greenish yellow pigment as those from the year before, but pinkish beige colonies (more typical of the species) were also abundant. Moreover, both types were often recovered from the same individual.

A new crop of first year juveniles that was deployed off of Martha's Vineyard in the summer of 2004 also developed JOD (Maloy et al. 2007). Like the survivors from 2003, high numbers of both pinkish-beige isolates and greenish-yellow variants were present in affected oysters. However, weekly sampling of this population revealed that the relative proportion of each phenotype was not stable $(F=48.48, \mathrm{p}<0.001)$. Specifically, the numbers of greenish colonies diminished over time $(F=7.83, \mathrm{p}<0.001)$ as the pink isolates became the dominant component of the flora and all but displaced the green pigmented variant by the end of the mortality episode (Fig. 2).

JOD mortality accompanied by Roseovarius crassostreae colonization was also observed in 2 additional populations of adult Crassostrea virginica from Martha's Vineyard in 2004. In one group (77.5 \pm $10.5 \mathrm{~mm}$ shell height [mean $\pm \mathrm{SD}$ ]) the cumulative mortality rate was approximately $20 \%$, and $R$. crassostreae was recovered from these oysters at levels of up to

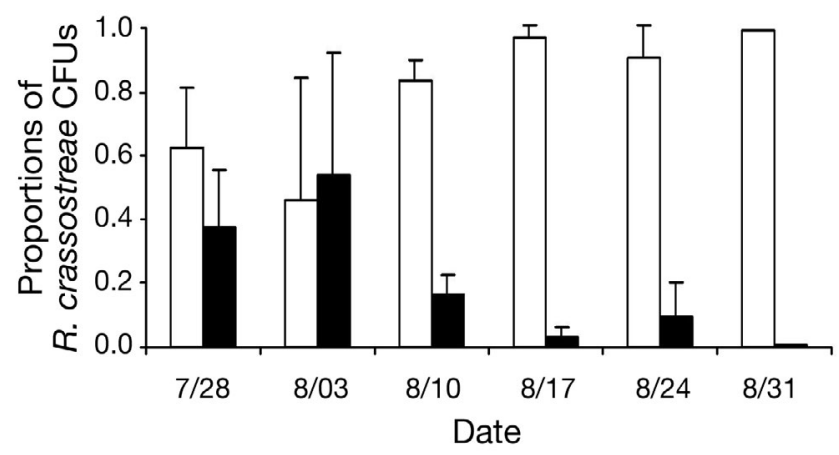

Fig. 2. Roseovarius crassostreae. Occurrence of a pink-pigmented phenotype (GS II-A; open columns) and a greenishyellow variant (GS I-E; solid columns) as a proportion of total $R$. crassostreae recovered over time from a population of cocolonized oysters in Martha's Vineyard during 2004. Data represent the mean (+SD) from 4 to 8 oysters for each date (mo/d), except for the final sampling date when only one oyster was found to be colonized by both forms 
$95 \%$ of total colonies. All oysters examined $(\mathrm{n}=20)$ from this group had some degree of conchiolin; however, in about $50 \%$ of the individuals, it was little more than yellow discoloration around the mantle periphery (Fig. 3A). Heavier rings and blisters of conchiolin (as seen in Fig. 3B) were present in the remaining oysters. In a few individuals extensive mantle retraction and heavy fouling were observed around the peripheral margins of the internal valves surfaces. Such signs cooccurred with multiple layers of conchiolin, including recently deposited material (yellow to olive green in color) and old deposits (dark brown to green in color) (Fig. 3C). In addition, successive ridges of conchiolin were observed in some oysters (Fig. 3D), which are also consistent with repeated bouts with the disease.

\section{Genetic characterization of isolates}

16S rRNA gene sequence analyses

We previously reported that regardless of the year or location, Roseovarius crassostreae isolates share a $\geq 99.8 \%$ sequence identity across an unambiguous $1310 \mathrm{bp}$ region of the 16S rRNA gene (Boettcher et al. 2005). The $16 \mathrm{~S}$ rDNA sequences were also obtained for 26 additional isolates used in this study and, likewise, all were 99.8 to $100 \%$ identical to that of the type strain R. crassostreae CV919-312 ${ }^{\mathrm{T}}$ (GenBank accession number AF114484).

\section{Analysis of the 16S-23S ITS region}

Prior analysis of the ITS region for genetic variation revealed the occurrence of 2 distinct RFLP patterns among Roseovarius crassostreae isolates, which have been designated as GSI and GSII (Maloy et al. 2005). In this study direct sequencing of 103 isolates revealed that the GSI and GSII isolates have ITS regions of approximately 1255 and 1235 bp in length, respectively. The most notable difference between the 2 signatures is a $100 \mathrm{bp}$ region of low sequence identity $(<25 \%)$ immediately downstream of the Ala-tRNA gene (Fig. 4). The variable Ava I site is found within this region of the GSI sequence in addition to a $20 \mathrm{bp}$
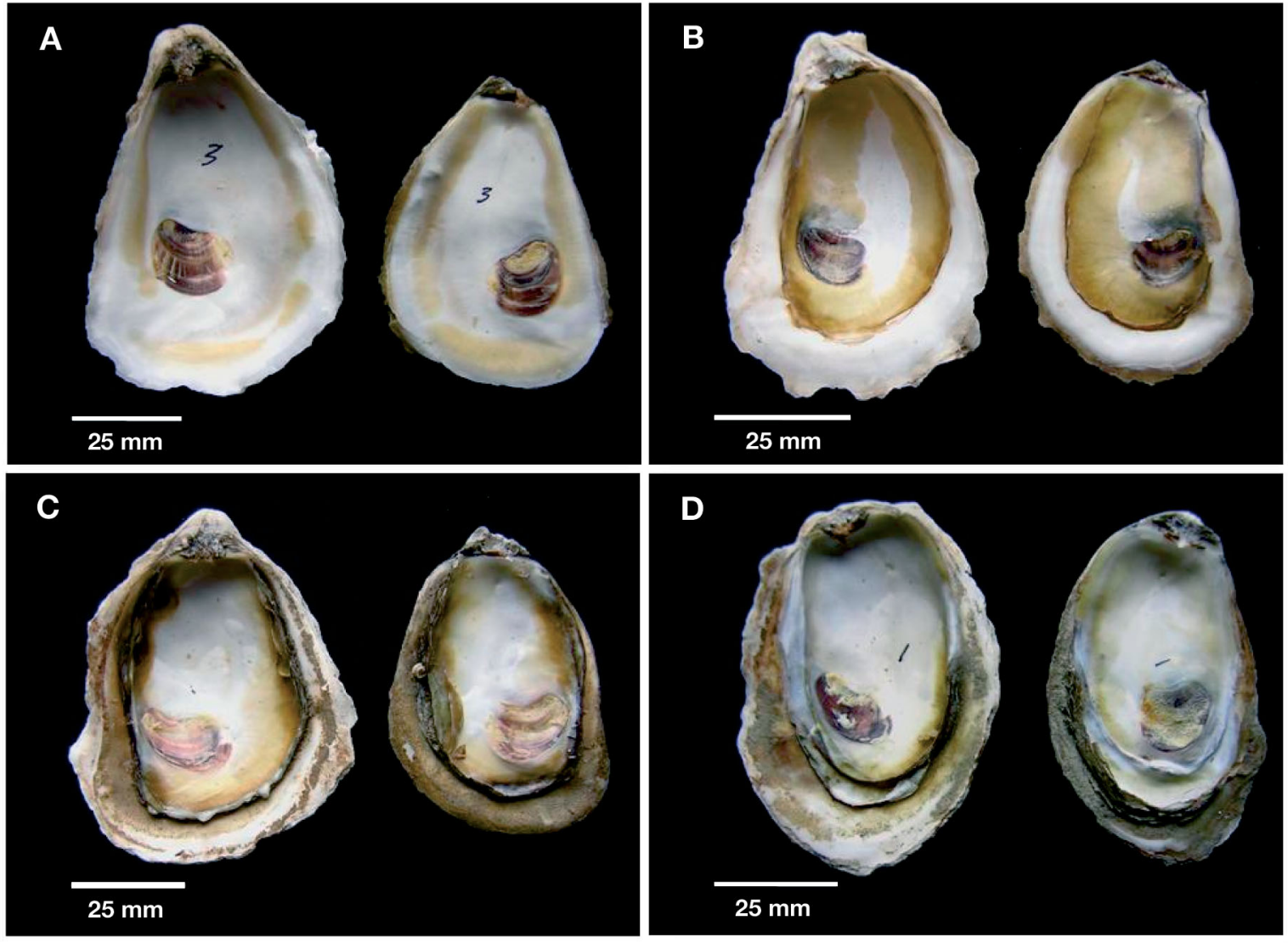

Fig. 3. Crassostrea virginica. JOD-affected adult oysters obtained from Martha's Vineyard in 2004. Approximately $50 \%$ of the individuals had minimal shell discoloration (A), while more typical conchiolin was observed in the others (B). Multiple layers of conchiolin (C) and/or successive ridges of conchiolin (D) were observed in other individuals which appeared to be chronically affected by the disease 


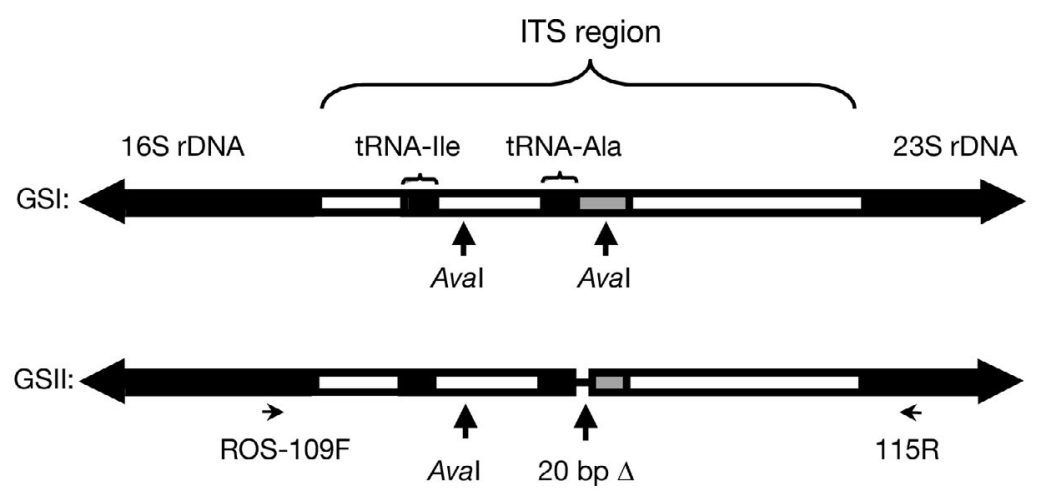

Fig. 4. Roseovarius crassostreae. Scale representation of the 16S-23S rDNA ITS region of the bacterium. The 2 genetic signatures are distinguished by a $100 \mathrm{bp}$ region of low sequence identity (grey) which includes the variable Ava I site and a $20 \mathrm{bp}$ region not found in isolates with genetic signature II (GSII).

Positions of the PCR primers and transfer RNA (tRNA) genes also shown often, isolates from any given JOD epizootic were found to share the same genetic signature. For example, the Roseovarius crassostreae isolated on Maine's Damariscotta River during 1997 and 1998 were GSI, while all Maine isolates examined since 2000 have been GSII. Thus, it was unexpected when both genetic signatures were simultaneously discovered in Oyster Bay, New York, in 2002 (2 isolates were GSI, while a third produced a GSII restriction pattern). Then in 2003 the first definitive evidence of co-infection during an active epizootic was found at Eastham on Cape Cod Bay, Massachusetts. Both genetic signatures were isolated from this population and in one instance from the same individual. At Katama Bay (in segment not found in the GSII sequence. Using the PCR primers described here, the GSI amplicon is characterized by 3 Ava I fragments of approximately 310, 435 and 510 bp. Digestion of GSII amplicons results in only 2 fragments which are about 435 and 800 bp in length.

A total of 506 isolates (at least 1 from each of 321 individual oysters) were first classified as either GSI or GSII using the PCR-RFLP approach (Table 1). Most nearby Martha's Vineyard) only GSI-type $R$. crassostreae were recovered in 2003, while in Oyster Bay that year, all isolates were GSII.

In addition to the divergence distinguishing GSI and GSII isolates, direct sequencing of ITS amplicons ( $\mathrm{n}=$ 103) revealed additional minor genetic variation among isolates. A total of 11 unique genotypes were discovered (Genbank accession numbers AF114484 and DQ341296-DQ341305), 6 of which belonged to

Table 2. Roseovarius crassostreae. Occurrence of genotypes according to state, year and site of isolation. Genotype data indicate the number of isolates with each genotype (as determined by sequencing). Abbreviations same as in Table 1

\begin{tabular}{|c|c|c|c|c|c|c|c|c|c|c|c|c|c|}
\hline \multirow{2}{*}{ State } & \multirow{2}{*}{ Year } & \multirow{2}{*}{ Site } & \multirow[b]{2}{*}{ I-A } & \multirow[b]{2}{*}{ I-B } & \multirow[b]{2}{*}{$\mathrm{I}-\mathrm{C}$} & \multirow[b]{2}{*}{ I-D } & \multirow[b]{2}{*}{ I-E } & \multirow{2}{*}{$\begin{array}{c}\text { Genotype } \\
\text { I-F }\end{array}$} & \multirow[b]{2}{*}{ II-A } & \multirow[b]{2}{*}{ II-B } & \multirow[b]{2}{*}{ II-C } & \multirow[b]{2}{*}{ II-D } & \multirow[b]{2}{*}{ II-E } \\
\hline & & & & & & & & & & & & & \\
\hline \multirow[t]{10}{*}{ ME } & 1997 & DR & 6 & & & & & & & & & & \\
\hline & 1998 & DR & 6 & & & & & & & & & & \\
\hline & 2000 & DR & & & & & & & 2 & & & & \\
\hline & 2000 & MB & & & & & & & 1 & & & & \\
\hline & 2000 & NM & & & & & & & 2 & & & & \\
\hline & 2001 & DR & & & & & & & 2 & & & & \\
\hline & 2001 & SR & & & & & & & 2 & & & & \\
\hline & 2002 & DR & & & & & & & 13 & & & & \\
\hline & 2003 & DR & & & & & & & 3 & & & & \\
\hline & 2004 & DR & & & & & & & 4 & & & & \\
\hline \multirow{6}{*}{ NY } & 2002 & OB & & 1 & 1 & & & & & 1 & & & \\
\hline & 2003 & OB & & & & & & & & & 2 & 2 & \\
\hline & 2003 & MT & & & & 1 & & & & & & & \\
\hline & 2004 & OB & & 1 & & & & & & 2 & & 1 & \\
\hline & '2004 & MT & & & & & & 1 & & 3 & 2 & 1 & \\
\hline & 2004 & $\mathrm{SH}$ & & & & & & & & & & 3 & 1 \\
\hline \multirow[t]{6}{*}{ MA } & 2003 & $\mathrm{~KB}(\mathrm{MV})$ & & & & & 7 & & & & & & \\
\hline & 2003 & EP (MV) & & & & & 3 & & & & & & \\
\hline & 2003 & $\mathrm{DN}(\mathrm{CC})$ & & & & & & & & 2 & & & \\
\hline & 2003 & EA (CC) & & & 3 & & & & & & 3 & & \\
\hline & 2003 & $\mathrm{BS}(\mathrm{CC})$ & & & & & & & & & 3 & & \\
\hline & 2004 & KB (MV) & & & & & 6 & & 12 & & & & \\
\hline
\end{tabular}


the GSI group, and 5 of which had the GSII genetic structure (Table 2). In some instances the sequence data provided additional evidence that certain epizootics originated from the same (or single) infective genotype. For example, the GSI isolates from Maine were also $100 \%$ identical to each other across the entire ITS region. Because this was the first GSI sequence determined, it was designated I-A (Genbank accession number AF114484). Similarly, all GSII isolates from Maine shared $100 \%$ identity with each other across the entirety of the ITS region. These were designated II-A (Genbank accession number DQ341296). Representative GSI and GSII isolates from the other epizootics were also analyzed, and each new sequence within each group was assigned a successive letter (Table 2 and Genbank accession numbers DQ341297-DQ341305).

In 3 instances a single isolate was found that had a unique sequence (I-D, I-F and II-E). Representatives of the other genotypes were more frequently obtained and usually shared some other common characteristic and/or geographic origin (Table 2). For example, isolates with the I-A sequence were only recovered from cases of JOD in Maine before 2000. All the greenish yellow strains were genotype I-E and were isolated exclusively from sites on Martha's Vineyard. The II-A genotype was believed to be unique to Maine until 2004, when isolates with this sequence were recovered on Martha's Vineyard from JOD affected adults and survivors of a 2003 epizootic. In 2004 a first-year oyster crop on Martha's Vineyard became co-colonized with both the I-E and IIA genotypes, and the latter appeared to have a competitive advantage (as discussed previously; Fig. 2). Isolates with the I-B and II-D sequence were recovered only from New York oysters, and similarly all but one of the II-B isolates originated from New York.

Those isolates that exhibited minor sequence variations in the 16S rDNA sequence also shared common ITS genotypes. For example, the single isolate with the I-D genotype had a unique guanine (instead of an adenine) at position 1188 of the Roseovarius crassostreae type strain $16 \mathrm{~S}$ sequence. All II-B isolates had the same adenine to guanine change at position 53 of the $16 \mathrm{~S}$ type strain sequence, and all II-D isolates had a guanine at position 89 instead of an adenine. There was no obvious correlation with virulence, but genotypes I-A, I-E and II-A have been isolated from epizootics with comparatively high mortality rates (usually $50 \%$ or greater).

\section{Phylogenetic analysis}

The phylogenetic relationships among the genotypes were evaluated using distance analysis. As

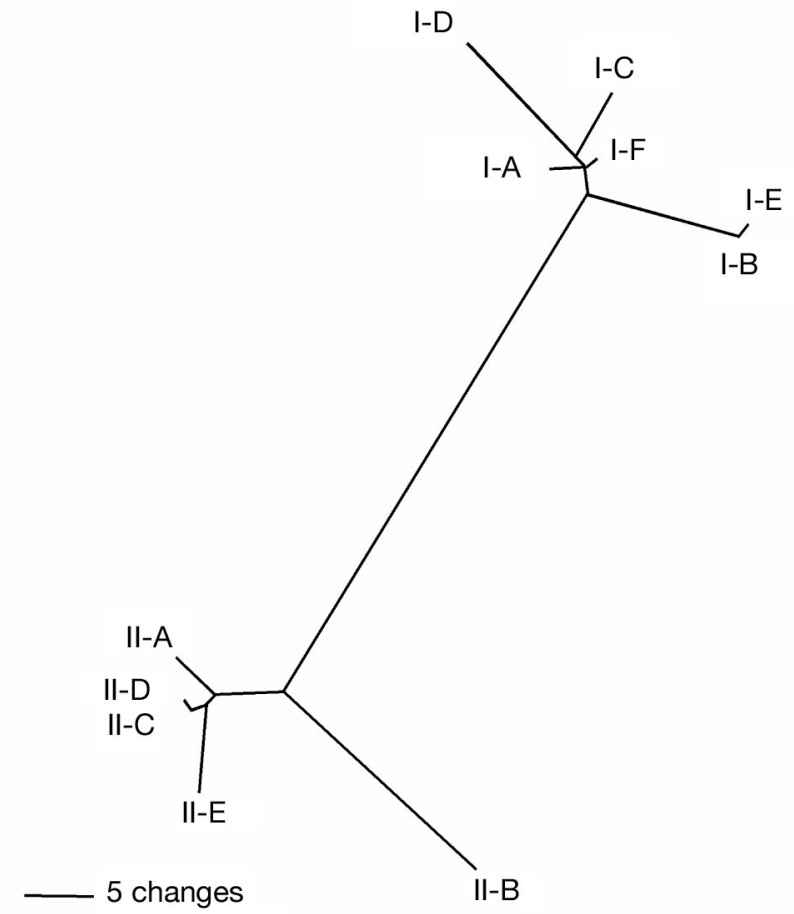

Fig. 5. Unrooted phylogram depicting the relatedness of Roseovarius crassostreae ITS genotypes. The tree was constructed using a heuristic search of 1027 characters with the optimality criterion set to distance. See Table 2 for the geographic distribution of these strains

expected all strains fell into one of 2 major groups according to the Ava I-categories of GSI and GSII (Fig. 5). There was no obvious tendency, however, for closely related genotypes to be found in neighboring geographical areas.

\section{DISCUSSION}

Regardless of the time or place of isolation (Fig. 1), all Roseovarius crassostreae studied to date have 16S rRNA genes that are either $100 \%$ identical to the type strain CV919-312 ${ }^{\mathrm{T}}$ or that differ at only 1 or 2 positions (Boettcher et al. 1999, 2005, and the present study). Informative divergence does, however, exist within the 16S-23S rDNA ITS region and this has provided a means to study the epizootiology of JOD as described herein. First, PCR amplification of the ITS region followed by Ava I restriction enzyme analysis was used to assign isolates to 1 of 2 groups (GSI or GSII). The results provided evidence that most epizootics were the result of infection by a single strain; a finding consistent with our observation that all colonies recovered from a given epizootic tend to look identical. These outbreaks could, therefore, have arisen from a single 
infection event (i.e. index case). However, in studies of isolates from New York and Massachusetts, we discovered the involvement of different genetic signatures in the same epizootic (Table 1), even within the same individual. Clearly, there must have been multiple and/or successive infection events among the oysters within these populations.

The ITS region of isolates was also directly sequenced to detect additional variation. Eleven distinct genotypes were identified, some of which were unique to specific areas (Table 2). Eight of the sequences were found among Roseovarius crassostreae isolated from New York, while only 2 have been found in Maine. Five of the sequences have been found among isolates from Massachusetts and, until recently, one of those (II-A) was believed to be exclusive to Maine. These data indicate that pathogenic $R$. crassostreae strains are widespread in the environment and once established at a grow-out site a given genotype can persist from year to year.

What insights then can be gained into the ecology of Roseovarius crassostreae? It has been established that sediments are an important niche for other members of the Roseobacter clade (Buchan et al. 2005). Also, because JOD does become enzootic at certain sites, and anecdotal observations from such areas indicate epizootics tend to follow substrate disturbances (e.g. storms and dredging), it is possible $R$. crassostreae can at least survive in sediments. But how might they become dispersed? In the absence of human involvement the only reasonable alternative is transport by water movement. We, therefore, analyzed the distribution patterns of genotypes to determine if they reflected the prevailing coastal currents. From Maine regional circulation moves predominately south and west along the coast to Massachusetts (e.g. see Pettigrew et al. 2005). From southern portions of Cape Cod, Massachusetts, denser coastal water flows west into Long Island Sound, New York, while less saline surface waters flow northeast out of the sound before largely diverting southeast through the Block Island Sound (Kim \& Bokuniewics 1991, Kincaid et al. 2003, Ullman \& Codiga 2004). In addition, wind-driven events can intensify the general circulation pattern of Long Island Sound (Signell et al. 1998, 2000), potentially pushing surface waters back to the Rhode Island and Massachusetts coasts. Thus, a mechanism exists for bidirectional exchange of waters between Massachusetts and Long Island Sound, while transport from Maine is expected to be 1-way. In fact, all Cape Cod genotypes have been detected in New York waters, but not vice versa. Furthermore, because of the high diversity of genotypes present in New York, it seems that these waters may serve as a central reservoir (or perhaps repository) for infectious $R$. crassostreae.
Whatever the case, according to the phylogenetic analyses (Fig. 5), mixing and/or transport of strains between Cape Cod and Long Island Sound occurs on a shorter time scale than diversification within the ITS.

The circulation models do not, however, explain why Martha's Vineyard has remained comparatively isolated, nor why (with one exception, described in the next paragraph) Maine genotypes have not been detected elsewhere. Perhaps there is some biological barrier related to the physiology or ecology of Roseovarius crassostreae. In addition to being present in sediments, members of the Roseobacter clade (which contains the genus Roseovarius) are abundant in the upper surface layers of coastal seawater (Buchan et al. 2005). Roseobacters also tend to be associated with phytoplankton (e.g. González et al. 2000, Biebl et al. 2005), and $R$. crassostreae-like sequences have been detected in diatom cultures (Schäfer et al. 2002). Biochemically, Roseovarius spp. are able to use a major algal osmolyte (Buchan et al. 2005). Therefore, it is possible that the ecology of $R$. crassostreae is partly tied to the abundance and distribution of some species of phytoplankton. Roseovarius crassostreae also grows optimally at salinities below that of full strength seawater (Boettcher et al. 2005) and, thus, may survive best in near shore estuarine environments. The fact that such a diversity of $R$. crassostreae genotypes are found in Long Island Sound (where salinities typically do not exceed 27 ppt; Kim \& Bokuniewics 1991) seems to support this hypothesis.

The emergence of a genotype in Martha's Vineyard in 2004, which was previously believed to be unique to Maine, warrants specific consideration. The II-A genotype could have recently arrived from Maine via the prevailing currents. However, if this is the case, it seems unusual that it has never been detected among Cape Cod or New York oysters. Alternatively, the strain may have been present in Martha's Vineyard waters for an extended period of time, but not until recently were conditions favorable for its proliferation and/or propensity to cause disease. Another possibility is that the strain was unintentionally introduced as a result of seed transfer. In fact, there are unconfirmed reports that seed originating from Maine waters was deployed in Martha's Vineyard in 2003.

The appearance of genotype II-A on Martha's Vineyard also offered a unique opportunity to study the dynamics of a co-infection event. Both this and the greenish yellow native genotype (I-E) were isolated from diseased oysters there in 2004, but as the epizootic progressed, the proportion of Roseovarius crassostreae that was I-E declined significantly (Fig. 2). Analyses of the previous year's JOD survivors also provided evidence that the II-A strain is able to colonize oysters that are recovering from a challenge with the 
I-E strain. The selective pressures are unknown, but these observations provide the first evidence that not all genotypes are equal in their ability to persist in association with the host. Compared to I-E, the II-A genotype may colonize more quickly and/or have a higher tolerance for the host defense response. Stocks of oysters may also become somewhat adapted to indigenous $R$. crassostreae while remaining highly susceptible to foreign genotypes. Finally, the observed imbalance may be a result of direct competition and/or antagonism between the genotypes within the host. (Interestingly, growth of the II-A strain in the laboratory is actually inhibited by close proximity to I-E colonies; A. P. Maloy \& K. J. Boettcher unpubl.). Whatever the explanation, these data represent a starting point for understanding how $R$. crassostreae interacts with the host and other conspecifics.

This study was also the first to document JOD mortality (and to confirm the involvement of Roseovarius crassostreae) among individuals that were more than 1 yr old. Mortality rates were low compared to juvenile populations, apparently as a result of increased immunocompetence (see also Paillard et al. 1996). For example, yellowing of the shell was seen in $50 \%$ of the oysters and was restricted largely to the periphery of the mantle margin (Fig. 3A). Such yellowing seems to have resulted from small amounts of conchiolin that were slowly incorporated into the foliated valve matrix without forming surface layers and without a disruption in growth. In other populations we have observed fractures in the shells of JOD survivors that clearly reveal conchiolin deposits underlying yellowed areas (A. P. Maloy \& K. J. Boettcher unpubl.). Still, the conchiolin response in adults is not uncommon and can result from a variety of sublethal stressors such as boring sponges Cliona spp., worms Polydora spp. (Carriker 1996, Ford \& Tripp 1996) and perhaps even anthropogenic contaminants. However, there were no pest species associated with adult oysters from Martha's Vineyard, and although an anthropogenic contaminant cannot be ruled out, it is not suspected at this location. Active conchiolin deposition was evident among the other adults in this population (Fig. 3B-D). The presence of successive ridges of conchiolin, the older of which were partially calcified (Fig. 3D), indicates that this challenge was chronic (i.e. extending at least into the previous growing season). Taken together, these results are consistent with $R$. crassostreae being a great threat to juvenile, but not, typically, adult oysters.

During the course of investigating the epizootics given in Table 1, several thousand oysters were examined and some general trends were evident. First, while the actual manifestation of JOD was largely independent of location, the signs were most obvious in those populations that were undergoing a period of robust and steady growth before the disease challenge. There was, however, an apparent relationship between the occurrence of certain signs and oyster size. For example, the simultaneous occurrence of all signs was most consistently observed among mid-sized oysters between 10 and $30 \mathrm{~mm}$ shell height. In contrast, affected oysters less than about $10 \mathrm{~mm}$ were easily identified by uneven valve margins and high mortality rates $(>50 \%)$, but conchiolin deposition was light or nonexistent. The largest individuals (>30 mm) typically had extensive conchiolin deposits, although the effects on growth and tissue condition were less pronounced and mortality rates were generally low (e.g. $<10 \%)$. The negligible metabolic resources possessed by smaller oysters (i.e. $<10 \mathrm{~mm}$ ) may explain why conchiolin deposition is rarely seen among this size class (K. J. Boettcher pers. obs.). In contrast, the presence of conchiolin is a much better diagnostic aid in the larger individuals (i.e. $>10 \mathrm{~mm}$ ), which succumb less quickly to the disease and are strong enough to mount this host response (see also Ford \& Borrero 2001). This means that many cases of JOD among small oysters may be misdiagnosed as starvation when no conchiolin is observed. Bacteriological analyses in such cases can confirm colonization by Roseovarius crassostreae. At the other extreme, many cases of JOD among oysters $>25 \mathrm{~mm}$ are probably missed because of low mortality rates and a reduced effect on growth. In these cases, internal deposits of conchiolin and the presence of $R$. crassostreae would be diagnostic.

In summary, we have identified informative divergence in the 16S-23S rDNA ITS region of Roseovarius crassostreae and analyzed the distribution of genotypes at geographically and temporally distant epizootics. The data suggest that most JOD epizootics in the northeastern USA have resulted from independent acquisition of pathogenic $R$. crassostreae at the respective grow-out sites. The data are also consistent with the lack of an association of JOD with particular broodstock and/or hatcheries (Bricelj et al. 1992, Barber et al. 1998, Ford \& Borrero 2001). The distribution of genotypes south of Maine appears to be mediated by water currents, and the greatest diversity is concentrated around New York. $R$. crassostreae was found to persist in JOD survivors, and once established, a particular genotype was often involved in successive epizootics. These data have important implications for JOD management. For example, if $R$. crassostreae become locally enriched at sites of prolonged oyster culture, crop rotation (i.e. occasionally moving grow-out sites) and separating juveniles from older cohorts may prove profitable. Growers should also, whenever possible, obtain assurance that purchased seed has not been in contact with JOD 
endemic waters. A recently developed PCR assay (Maloy et al. 2005) may prove useful in screening seed for the presence of $R$. crassostreae prior to deployment. Still, because $R$. crassostreae seems to have a cosmopolitan distribution, good husbandry and the use of resistant stocks will probably provide the best long term approaches to managing JOD.

Acknowledgements. We thank S. Blair, J. Blake, R. Clime, R. Garrison, P. Horne, R. Karney, E. J. Lewis, T. Manicotti, W. Mook, D. Relyea, J. Richards, G. Rivara, R. Scheffer, D. Schweitzer, and B. and W. Walton for providing oyster samples, and C. Boardman, K. Geaghan, R. McLeod and J. Gunther for invaluable laboratory assistance. We also gratefully acknowledge the expert technical support of P. Singer at the University of Maine's DNA Sequencing Facility and thank J. Churchill and D. Kennedy for helpful comments on the manuscript. This study was funded by the Maine Agricultural and Forest Experiment Station, the Maine Aquaculture Innovation Center and by a Maine/New Hampshire Sea Grant award to K.J.B. and B.J.B. (R-01-01). This is publication 2958 of the Maine Agricultural and Forest Experiment Station.

\section{LITERATURE CITED}

Barber BJ, Carnegie RB, Davis CV, Mook W (1996) Effect of timing of seed deployment on growth and mortality of oysters, Crassostrea virginica, affected by juvenile oyster disease (JOD). J World Aquacult Soc 27(4):443-448

Barber BJ, Davis CV, Crosby MA (1998) Cultured oysters, Crassostrea virginica, genetically selected for fast growth in the Damariscotta River, Maine, are resistant to mortality caused by juvenile oyster disease (JOD). J Shellfish Res 17(4):1171-1175

Biebl H, Allgaier M, Lünsdorf H, Pukall R, Tindall BJ, Wagner-Döbler I (2005) Roseovarius mucosus sp. nov., a member of the Roseobacter clade with trace amounts of bacteriochlorophyll a. Int J Syst Evol Microbiol 55(6):2377-2383

Boettcher KJ, Ruby EG (1990) Depressed light emission by symbiotic Vibrio fischeri of the sepiolid squid Euprymna scolopes. J Bacteriol 173(7):3701-3706

Boettcher KJ, Barber BJ, Singer JT (1999) Use of antibacterial agents to elucidate the etiology of juvenile oyster disease (JOD) in Crassostrea virginica and numerical dominance of an $\alpha$-Proteobacterium in JOD-affected animals. Appl Environ Microbiol 65(6):2534-2539

Boettcher KJ, Barber BJ, Singer JT (2000) Additional evidence that juvenile oyster disease is caused by a member of the Roseobacter group and colonization of nonaffected animals by Stappia stellulata-like strains. Appl Environ Microbiol 66(9):3924-3930

Boettcher KJ, Geaghan KK, Maloy AP, Barber JB (2005) Roseovarius crassostreae sp. nov., a member of the Roseobacter clade and the apparent cause of juvenile oyster disease (JOD) in cultured eastern oysters. Int J Syst Evol Microbiol 55(4):1531-1537

Boettcher KJ, Smolowitz R, Lewis EJ, Allam B and 7 others (2006) Juvenile Oyster Disease (JOD) in Crassostrea virginica: synthesis of knowledge and recommendations. J Shellfish Res 25(2):683-686

Bricelj VM, Ford SE, Borrero FJ, Perkins FO, Rivara G, Hillman RE, Elston RA, Chang J (1992) Unexplained mortalities of hatchery-reared, juvenile oysters, Crassostrea virginica (Gmelin). J Shellfish Res 11(2):331-347
Buchan A, González JM, Moran MA (2005) Overview of the marine Roseobacter lineage. Appl Environ Microbiol 71(10):5665-5677

Carriker MR (1996) The shell and ligament. In: Kennedy VS, Newell RIE, Eble AF (eds) The eastern oyster: Crassostrea virginica. Maryland Sea Grant College, College Park, MD, p 75-168

Davis CV, Barber BJ (1994) Size-dependent mortality in hatchery-reared populations of oysters, Crassostrea virginica, Gmelin 1791, affected by juvenile oyster disease. J Shellfish Res 13(1):137-142

Davis CV, Barber BJ (1999) Growth and survival of genetically selected eastern oysters, Crassostrea virginica (Gmelin 1791) affected by juvenile oyster disease. Aquaculture 178(3-4):253-271

Ford SE, Borrero FJ (2001) Epizootiology and pathology of juvenile oyster disease in the eastern oyster, Crassostrea virginica. J Invertebr Pathol 78(3):141-154

Ford SE, Tripp MR (1996) Diseases and defense mechanisms. In: Kennedy VS, Newell RIE, Eble AF (eds) The eastern oyster: Crassostrea virginica. Maryland Sea Grant College, College Park, MD, p 581-660

González JM, Simó R, Massana R, Covert JS, Casamayor EO, Pedrós-Alió C, Moran MA (2000) Bacterial community structure associated with a dimethylsulfoniopropionateproducing North Atlantic algal bloom. Appl Environ Microbiol 66(10):4237-4246

Gürtler V, Stanisich VA (1996) New approaches to typing and identification of bacteria using the 16S-23S rDNA spacer region. Microbiology (SGM) 142(1):3-16

Jensen MA, Webster JA, Straus N (1993) Rapid identification of bacteria on the basis of polymerase chain reactionamplified ribosomal DNA spacer polymorphisms. Appl Environ Microbiol 59(4):945-952

Kim BH, Bokuniewicz HJ (1991) Estimates of sediment fluxes in Long Island Sound. Estuaries 14(3):237-247

Kincaid C, Pockalny RA, Huzzey LM (2003) Spatial and temporal variability in flow at the mouth of the Narragansett Bay. J Geophys Res 108(C7):3218, dio:10.1029/ 2002JC001660

Lane DJ (1991) 16S/23S rRNA sequencing. In: Stackebrandt E, Goodfellow M (eds) Nucleic acid techniques in bacterial systematics. John Wiley \& Sons, New York, p 115-175

Lewis EJ (2001) Juvenile oyster disease (JOD) and management strategies: a review. Bull Natl Res Inst Aquacult (Suppl)5:101-109

Lewis EJ, Farley AC, Small EB, Baya AM (1996) A synopsis of juvenile oyster disease (JOD) experimental studies in Crassostrea virginica. Aquat Living Resour 9(2): 169-178

Maloy AP, Boettcher KJ (2003) Roseimarina crassostreae (gen. no., sp. nov.) associated with JOD-signs in the absences of significant mortalities, and first isolation from a New York epizootic. J Shellfish Res 22(1):343

Maloy AP, Barber BJ, Boettcher KJ (2005) A PCR-based diagnostic assay for the detection of Roseovarius crassostreae in Crassostrea virginica affected by juvenile oyster disease (JOD). Dis Aquat Org 67(1-2):155-162

Maloy AP, Ford SE, Karney RC, Boettcher KJ (2007) Roseovarius crassostreae, the etiological agent of Juvenile Oyster Disease (now to be known as Roseovarius Oyster Disease) in Crassostrea virginica. Aquaculture doi: 10.1016/j.aquaculture.2007.04.008

Paillard C, Ashton-Alcox K, Ford SE (1996) Changes in bacterial densities and hemocyte parameters in oysters affected by juvenile oyster disease. Aquat Living Resour 9(2): $145-158$ 
Pettigrew NR, Churchhill JH, Janzen CD, Magnum LJ and 5 others (2005) The kinematic and hydrographic structure of the Gulf of Maine Coastal Current. Deep-Sea Res II 52(19-21):2369-2391

Schäfer H, Abbas B, Witte H, Muyzer G (2002) Genetic diversity of 'satellite' bacteria present in cultures of marine diatoms. FEMS Microbiol Ecol 42(1):25-35

Signell RP, Knebel HJ, List JH, Farris AS (1998) Physical processes affecting the sedimentary environments of Long Island Sound. In: Spaulding M, Blumberg AF (eds) Proc 5th Int Conf Estuar Coast Model. American Society of Civil Engineers, New York, p 400-412

Editorial responsibility: Richard Cawthorn, Charlottetown, Prince Edward Island, Canada
Signell, RP, List JH, Farris AS (2000) Bottom currents and sediment transport in Long Island Sound: a modeling study. J Coastal Res 16(3):551-566

Söller R, Hirsch P, Blohm D, Labrenz M (2000) Differentiation of newly described Antarctic bacterial isolates related to Roseobacter species based on 16S-23S rDNA internal transcribed spacer sequences. Int J Syst Evol Microbiol 50(2):909-915

Ullman DS, Codiga DL (2004) Seasonal variation of a coastal jet in the Long Island Sound outflow region based on HF Radar and Doppler current observations. J Geophys Res 109(C07506), doi:10.1029/2002JC001660

Submitted: November 15, 2006; Accepted: April 23, 2007 Proofs received from author(s): June 12, 2007 